\title{
Utilization of Information Technology for Inbistro's Tenants as a Digital Marketing Strategy Media
}

\author{
Silvester Dian Handy Permana ${ }^{1}$, Ketut Bayu Yogha Bintoro ${ }^{2}$ \\ \{handy@trilogi.ac.id ${ }^{1}$, ketutbayu@trilogi.ac.id²\} \\ ${ }^{1,2}$ Informatics Universitas Trilogi, Jakarta, Indonesia
}

\begin{abstract}
The role of information technology in this era is very important for all groups, especially in the micro-economic sector. In year 2018, the economic climate in Indonesia has grown steadily at $5 \%$. This was accompanied by various micro-economic sectors which began to grow in Indonesia. However, there are still many businessmen in the micro economic sector such as MSME that have not used information technology as their marketing strategy. This results in a limited range of product marketing from MSME and can close the potential for business development. This service activity was designed to answer the challenges of using appropriate information technology for MSME groups especially those who are fostered by the Trilogy Business Incubation (INBISTRO). The intended targets are non-ICT business groups such as Food \& Agriculture Products and Creative Products \& Designs. This activity utilizes information technology in the form of a website as company profile and online store along with its SEO so that it can be used by MSME groups to improve their business development. In addition, this activity produces a book to help other MSME in utilizing information technology. This activity is expected to help increase the reach and development of business to dominate the global market .
\end{abstract}

Keywords: Use of Information Technology ; E-business strategy ; Digital Economic Growth

\section{Introduction}

The economic growth of the Indonesian state is largely determined by the dynamics of the regional economy that are sourced from small and medium scale economic activities. The businesses included in the category of Micro, Small and Medium Enterprises (MSME) are the heart of the economy in the region. The MSME actors and big entrepreneurs cause the economic climate in Indonesia to grow stably at $5 \%$ in 2018 and are predicted to rise slightly to $5.2 \%$ by the end of 2018 . [1]

The role of information technology, especially in the field of the internet, has a huge impact on MSME actors. They can market their products widely and fulfill the rules of the e-business model [2]. Technology plays a role in providing information as a whole to prospective customers from outside the region and abroad. Of course if this role is run by all MSMEs, the pace of the Indonesian economy can grow rapidly in late 2018 or 2019 later [3].

Universitas Trilogi has a Trilogy Business Incubation, or abbreviated as Inbistro, where the Universitas Trilogi has a role as a mentor in the business of the MSME that it develops. This Inbistro has several tenants which are divided into 3 focus areas of incubation namely Information \& Communication Technology Products, Food \& Agriculture Products, and Creative \& Design Products. These three fields are certainly pioneering the business of MSME in order to become useful in society. 
However, two of the three focus areas of the incubation have not utilized information technology for the progress of their business. They still have a conventional marketing model that makes their business development not optimal.

In this service activity, MSME, especially Inbistro, will be able to use information technology to focus on their incubation. This activity fosters Inbistro tenants in creating a company profile website to market their products so that they are known to the public. The company profile website that will be created later will also provide a wealth of information to prospective customers in order to help sell their products both online and offline. In addition to the website, inbistro tenants will get guidance in making online stores that are part of the company profile website. The online shop makes it easy for Inbistro tenants to make buying and selling transactions. In the online store, all products will be presented by Inbistro tenants which can be ordered online with the ease of banking transactions in the payment. After having a website and online store, of course inbistro tenants are given debriefing about SEO (Search Engine Optimization). The SEO that will be given starts from basic SEO to advanced SEO. Basic SEO will discuss more about basic knowledge about SEO while advanced SEO will provide the best SEO strategy in order to become the top rank in search. This is so that online websites and stores are easily searched by potential customers in search engines such as Google, Bing, or Yahoo [4].

All of these activities will also be packaged in a book that can be read and followed by all MSME that have not used information technology for their business. This activity is expected to help improve marketing and business development to dominate the global market so that it can foster an economic climate in Indonesia

\section{Problem Solutions}

This activity is based on problems that arise in MSME. Not all MSME use information technology to support their business. Tenants who are fostered by the Universitas Trilogi in the Trilogy Business Incubator (Inbistro) also have not fully utilize information technology. Full utilization of information technology exist only in The Information and Communication Technology Products group. Whereas in food \& agricultural products and creative \& design products, information technology is not yet utilized.

Information technology acts as a digital marketing media for MSME products. With the existence of information technology, products can be widely known. The use of information technology at an early stage is to have a company profile in digital form. This is needed so that MSME can be known by the general public. The existence of this website can provide a wealth of information to the public about the products produced by MSMEs. The wealth of information provided to the public through this website can increase people's interest in buying MSME products [5].

In order to run a business on a digital platform, an online store is needed as a means of selling to the wider community. The online store can accommodate orders online. Order data in the form of buyer's name, shipping address, cellphone number, goods ordered, amount, and shipping method can be accommodated in the online store. With the existence of online stores for MSME actors, especially Inbistro tenants, can increase its economic activities [6].

Both activities above are preceded by an understanding of the digital era. MSME principals, especially Inbistro tenants, are expected to be able to firstly master the technology in the form of computers and the internet. After mastering the technology in the form of computers, the activity was 
preceded by buying a domain and an initial explanation of the wordpress system which act as a CMS (Content Management System) that will be used as the basis for the web company profile and online store [7].. After the assistance and development of the company profile website and online store for Inbistro tenants, there will also be material on SEO (Search Engine Optimization) where SEO is the solution to reach the top rank of the most often searched through search engines[8]. Search engines are digital literacy search media used by the public to search for all types of information. Examples of search engines are Google, Yahoo, and Bing. A digital strategy is needed to win the top rank in search engines [9]. The existence of mentoring activities in the making of company profile websites and online stores can help MSME players, especially Inbistro tenants in marketing their products widely. Assistance in the use of SEO can increase the number of community visits to websites and online stores so that they can attract interested people to buy the products they produce. It is expected from this activity MSME actors can use information technology to increase their economic productivity [10].

\section{Implementation Method}

The activities proposed in the implementation of this service are

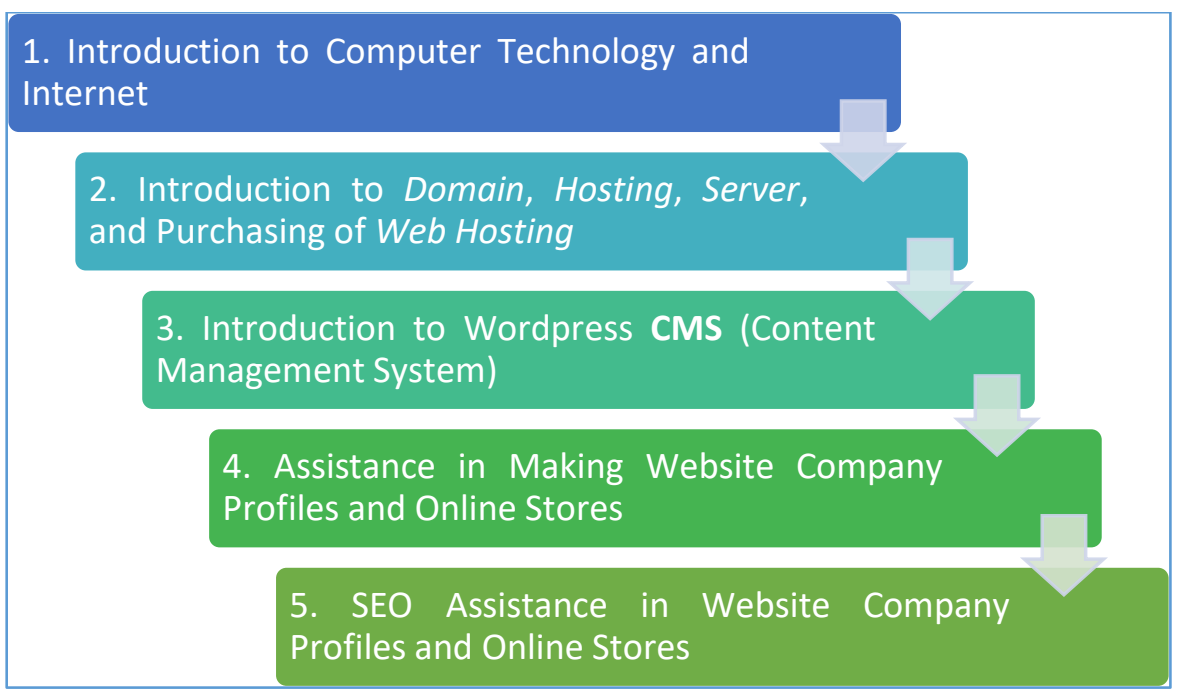

Fig 1 Flow of the process of implementing Service Activities

In Fig 1, there are 5 sub-activities used for this service. This service activity is divided into 5 sub-activities so that the material in the utilization of information technology can be thoroughly accepted. The details of the activities in this proposed service are:

1. Introduction to Computer Technology and Internet

Inbistro tenants are expected to be able to operate computer technology and get to know more about the internet. The provision of material on the internet is directed at being a supporter of digital economy. The digital economy by utilizing the internet in this era will also be explained in this session. This first session will be conducted by Community Service Members in this activity. 
2. Introduction to Domain, Hosting, Server, and Purchasing of Web Hosting

Domain, Hosting and Server recognition is needed to become a basic knowledge of the website and online store that will be created. Inbistro tenants cannot create websites and online stores without using a domain, hosting, and server. This session will also introduce how to host as a server on the website and online store that will be built. The second session will be conducted by the Chairperson of Service in this activity.

3. Introduction to Wordpress CMS (Content Management System)

WordPress CMS will be introduced as an online website and store creation platform. WordPress must be installed first before creating a website and online store. The stages of Wordpress installation will be explained to find out where the website will be stored in the file server. The third session will be conducted by the Chairperson of Service in this activity.

4. Assistance in Making Website Company Profiles and Online Stores

The making of this Company Profile and Online Shop Website will be carried out by Inbistro tenants themselves. The Chairperson and Members of the service accompany to make from the beginning to the end of making a Website Company Profile and Online Store.

5. SEO Assistance in Website Company Profiles and Online Stores

SEO is used to increase the number of people who open a Company Profile Website and Online Store by raising the top rank of the mostly searched in the search engines. In this session, procedures on how to use on site optimization and off site optimization will be provided. The Chairperson and Members of the service will be assisting the use of SEO by Inbistro tenants.

\section{Results of Activities}

Present service activities are carried out at the Universitas Trilogi by calling on all inbistro tenants. This activity was held in 5 sessions where each session had a different topic. Before this service activity was carried out, an exclusive interview was conducted with the head of Inbistro, Mr. Lahandi Baskoro. In the interview, the initial conditions of the Bistro in terms of economic income, business continuity and the use of information technology were obtained. From the interview, it was found that inbistro tenants focused on the field of food \& agricultural products incubation and creative $\&$ design products had not utilized information technology optimally. In which, they do not have a website to introduce products to the public at large. In the first session held for this community service which was to introduce information technology and the internet to all tenants in the Bistro. This is done so that all investors have a comprehensive understanding of the field of information technology and the internet. From the results of the service carried out, some inbistro tenants did not fully understand the use of information technology and the internet. Activities carried out in the context of the introduction of information technology and the internet have provided comprehensive insight into information technology and the use of the internet to sell their products. At this meeting also taught about the EBusiness method that is always held for every marketing through the internet, namely Reach, Richness, and Affliation. The result of this first activity was to introduce the products they made by posting on buying and selling forums in social media. The number of views obtained from this post averages 150 views per day. Some tenants have also been contacted by prospective customers to ask about the products being sold. 
The second session is the introduction of domain hosting servers along with the purchase of web hosting. This session was carried out so that each inbistro tenant has a thorough understanding of the domain, hosting, and server. In addition, they also have domain addresses that are used to promote their products. The results of this session are domain purchase and activation as well as inbistro tenant hosting. From this activity, there are 6 new hosting created. Domain and Hosting in this activity is purchased from an Internet Service Provider (ISP) named Webmaster. The hosting capacity used is 2 GB. This capacity is the standard hosting capacity for an MSME. It is expected that in the future all inbistro tenants can optimize their hosting.

The third session of this service is the introduction of Wordpress Content Management System (CMS). This session was carried out to provide knowledge about the beginning of web development. This activity starts from the introduction of CPanel which is a website for managing domains and hosting that have been purchased. This CPanel management includes creating an e-mail account with its own domain so that in the future the inbistro tenants will not use public e-mail like gmail or yahoo. The use of e-mail with its own domain can also increase the prestige of a business that is owned by increasing public trust in the business run by inbistro tenants. This activity also provides experience to all involved inbistro tenants to install Wordpress CMS. The installation process itself uses the Softaculous Apps Installer menu in CPanel. This activity generates a domain that has been installed Wordpress CMS and is ready to be designed and filled in with content.

The fourth session of this service event is Mentoring for Making a Company Profile Website and Online Shop. Assistance in making the company profile also uses the Wordpress CMS that was installed before at the third meeting. In this activity the inbistro tenants chose the theme provided by wordpress for the public. The selection of this theme is adjusted for the purpose of future website development whether using a company profile style or online shop style. Each selected theme has a different website configuration. In this session, assistance is made on website creation from theme selection to entering content or products to be marketed. This activity produces a website that is ready to be filled with various content regarding products that will be marketed through the website.

The ultimate session in this series of events was mentoring the use of SEO in company profile websites and online stores. SEO, which stands for Search Engine Optimization, is a way of optimizing so that search engines such as Google, Yahoo, or Bing can immediately find the website that we created. This session was carried out by looking at the way search engines find the website that we have created. This session also uses Google analytics installed on every web that we created to view traffic and visitor activities. Besides optimization techniques through off page and on page have also been implemented. One of them is by changing the meta data and all property attributes of all images on the website developed by inbistro tenants. The results of this activity can encourage new websites formed by inbistro tenants to be searchable on website search engines. 


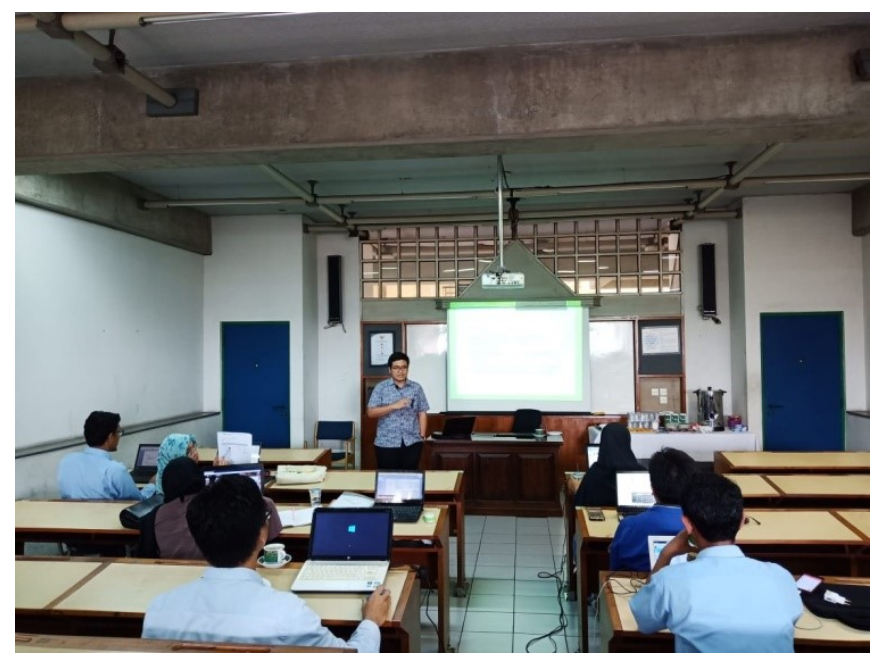

Fig 2. Community service activities involving inbistro's tenants

Fig 2 above is a picture of community service activity carried out in the classroom by inviting inbistro tenants. Each sessions were carried out within 120 to 150 minutes. This activity was held in November 2018. With this activity, it is expected that inbistro tenants can market products developed to a broad community by fulfilling the E-Business method, namely Reach, Richness, and Affiliation.

\section{Conclusion}

The conclusion that can be drawn from the results of this community service activity is to help inbistro tenants to be able to market their products through a website with the domain name of the MSME they have formed. This activity also encourages inbistro tenants to improve the economy in order to maintain the sustainability of the business they have developed. The result of all these activities is to increase the business growth of inbistro tenants by using information technology.

\section{References}

[1] Badan Pusat Statistik, "Ekonomi Indonesia Triwulan I 2018 Tumbuh 5,06 persen," Ekonomi Indonesia Triwulan I 2018 Tumbuh 5,06 persen, 2018. [Online].Available:https://www.bps.go.id/pressrelease/2018/05/07/1520/ekono mi-indonesia-triwulan-i-2018-tumbuh-5-06-persen.html.

[2] S. D. H. Permana, "E-marketing strategy in game industry with social media using e-business model," pp. 258-263, 2016.

[3] C. Mustika, "Dampak output GDP sektor pertanian terhadap masalah pembangunan ekonomi di Indonesia ( kemiskinan dan pengangguran )," vol. 1960, no. 1, pp. 22-28, 2018.

[4] D. S. T. Bin Hasri, Sigit Santoso, "Analisis Pengembangan Usaha Mikro Kecil 
Menengah Untuk Meningkatkan Pertumbuhan Ekonomi Sebagai Upaya Pengentasan Kemiskinan Dan Pengangguran Daerah Di Kabupaten Ngawi," $J$. Pendidik. Insa. Mandiri, vol. 2, no. 1, p. , 2014.

[5] B. C. Hartanto et al., "Perancangan dan Pembuatan Website E-Commerce untuk UMKM yang dibina oleh Universitas Kristen Petra," pp. 1-6, 2017.

[6] W. Lamine, S. Mian, A. Fayolle, M. Wright, M. Klofsten, and H. Etzkowitz, "Technology business incubation mechanisms and sustainable regional development," Journal of Technology Transfer, vol. 43, no. 5. pp. 1121-1141, 2018.

[7] A. Wahana, "RANCANG BANGUN MARKETPLACE PRODUK KEWIRAUSAHAAN MAHASISWA UPY BERBASIS CONTENT," J. Din. Inform., vol. 7, no. 1, pp. 73-81, 2018.

[8] A. Ullah, N. M. Nawi, E. Sutoyo, A. Shazad, S. Naqeeb, and M. Aamir, "Search Engine Optimization Algorithms for Page Ranking: Comparative Study," vol. 10, pp. 19-25, 2018.

[9] M. N. A. Khan and A. Mahmood, "A distinctive approach to obtain higher page rank through search engine optimization," Sadhana - Acad. Proc. Eng. Sci., vol. 43, no. 3, pp. 1-12, 2018.

[10] L. Sivanandam, "Competitive Analysis of Retail Websites through Search Engine Marketing Análisis competitivo de sitios web minoristas a través del marketing de búsqueda," vol. 14, no. 25, 2018. 